\title{
Truce on the US horizon for engineered organism releases
}

Washington

A LEADING group of US ecologists has stepped into the fracas over where to draw the line in regulating the release of genetically engineered organisms into the environment. The Ecological Society of America (ESA) last week proposed a scheme for determining the appropriate level of oversight for environmental releases, based on a "qualitative to semiquantitative" estimate of the degree of ecological risk.

Establishing procedures for permitting field tests of genetically engineered organisms has been a tortuous process for the

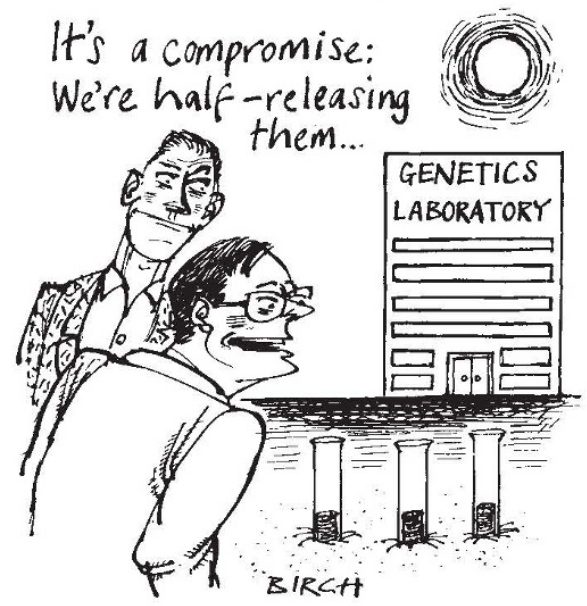

Environmental Protection Agency (EPA) and the Department of Agriculture - the two federal agencies given key regulatory jurisdiction within the Coordinated Framework for the Regulation of Biotechnology published in 1986 . While the agencies have drawn criticism for not being sufficiently cautious in preventing the release of potentially disruptive or dangerous organisms, they have also been attacked for attempting to stifle the innovations of the biotechnology industry.

The EPA drew up a set of rules last summer setting out several controversial proposals under the Toxic Substances Control Act (TSCA) and the Federal Insecticide, Fungicide and Rodenticide Act, the two statutes EPA is adapting to cover biotechnology.

One would establish a network of local 'environmental biosafety committees' to parallel the National Institutes of Health's institutional biosafety committees, which review recombinant DNA experiments (see Nature 331, 107; 1988). Another would create a streamlined TSCA Experimental Release Application for approving limited commercial field tests.

The draft rules leaked out last autumn, during review by the Reagan administration, before they could be published in the Federal Register for public comment.
Biotechnology trade associations and environmental groups have been clamouring to register their objections to the proposals ever since. Last week, the EPA sought to rectify the situation by publicly announcing that the documents were available, and by defining a comment period until the middle of May.

The most contentious issues in the proposed rules have been how EPA should determine which organisms should be subject to review, how extensively the agency should control commercial research and development activities, and whether research carried out at universities on behalf of companies should also be monitored.

The Ecological Society's outline does not address these issues, but instead lays out a sliding scale of scrutiny to be used on a case-by-case basis to assess the genetic changes made to the parent organism and the likely extent of changes in its behaviour in the environment.

The Ecological Society's plan was coordinated by James M. Tiedje of Michigan State University, who also served on the advisory panel for a report on the field-testing of genetically engineered organisms prepared last year by the US Office of Technology Assessment. Other environmental groups have expressed their approval of the plan, including such diverse organizations as the Conservation Foundation, the National Wildlife Federation and the Environmental Policy Institute/Friends of the Earth. Even Jeremy Rifkin of the Foundation on Economic Trends has added his approval: in its litigious tradition, the foundation has filed a petition through its attorney to force the EPA to consider the ESA's findings in rewriting its rules. Carol Ezzell

\section{Research foundation loses out in fund-raising failures}

\section{Washington}

While the National Institutes of Health (NIH) are trying to encourage closer ties between their researchers and industry, at least one researcher has found the commercial road to be rocky.

In the spring of 1988 , Robert Glazer of the National Cancer Research Institute received a $\$ 500,000$ grant from a pharmaceutical company for research on drug resistance. To make the money go further and avoid personal taxation, Glazer, with what he thought was the permission of his division director, established a foundation to administer the fund.

But in September last year, after the foundation had been established, NIH requested him to submit a formal application seeking approval for the foundation. One month later, the assistant director of the cancer institute recommended that the foundation be approved. But in November, NIH officials told Glazer that a more appropriate mechanism for using the money from the grant would be a Cooperative Research and Development Agreement (CRADA).

CRADAs were introduced last year under the Federal Technology Transfer Act of 1986 to promote collaboration between NIH researchers and industry (see Nature 336, 103; 1988). But Glazer's benefactor was uninterested in a CRADA, because the grant was not intended for commercial development purposes. Finally, in January, NIH rejected approval of Glazer's foundation.

Complicating the picture is a dubious scheme by Glazer to raise additional money for his foundation by means of a sweepstake in which participation was offered publicly. Glazer contracted the services of an agency, Watson and Hughey, to run his fund-raising campaign. The firm has run campaigns for several cancer charity organizations in the United States.

Under the scheme, solicitations were mailed to several hundred thousand people informing them that they were winners in a $\$ 5,000$ sweepstake, and asking that they claim their winnings with a reply and a donation for the foundation. But the sweepstake has several drawbacks. Most 'winners' receive only 10 cents, the bulk of donations appears to be absorbed in mailing costs and very little goes to the client. Watson and Hughey are currently being investigated in several states for alleged breaches of consumer laws. But Glazer insists that their operation is legal.

NIH officials deny they were influenced in their decisions on Glazer's foundation by the sweepstake scheme, which came to light after the National Cancer Institute's own in-house journal published a report on Watson and Hughey in January (Journal of the National Cancer Institute 81, 18 January, 1989).

Glazer has agreed to stop the fundraising and transfer his grant to another foundation associated with NIH. But he is furious that the cancer institute's journal revealed his sweepstake scheme after he had agreed to abandon it. "I haven't made a dime" out of the sweepstakes, Glazer says, who says he is considering taking legal action for violation of his privacy.
David Swinbanks 